\title{
Application of Problem Based Learning (PBL) Learning Model Environment- Based as an Effort to Improve the Quality of Class V SD Negeri Patemon 02 Semarang
}

\section{Septiani Evi Kurniawati}

\author{
SD Negeri Patemon 02 \\ septianievi91@gmail.com
}

\section{Article History \\ received $3 / 12 / 2020$}

\begin{abstract}
Learning has not provided a real picture to students. Due to limited methods, teachers need to use other methods. Teacher skills, student activities and learning outcomes have not been maximized. Based on the problem, it is necessary to apply an environment-based Problem Based Learning (PBL) learning model for students. The research uses a CAR research procedure which consists of four steps, namely planning, implementing action, observing, and reflecting. The research design consists of 4 stages in one cycle. The instrument of data collection used the technique of observation, interviews, documentation studies and evaluation sheets. The data analysis technique used qualitative and quantitative analysis. The results of teacher skills have a percentage of success in the first cycle of $76.56 \%$ and the second cycle of $89 \%$. The results of student activities have a percentage of $62.5 \%$ in the first cycle and $78 \%$ in the second cycle. The learning outcomes of students in the first cycle were $70.3 \%$ and the second cycle was $85.18 \%$. In conclusion, the environmental-based Problem Based Learning $(P B L)$ model that is applied can improve the quality of learning.
\end{abstract}

Keywords: problem based learning, environment based, classroom action research

\begin{abstract}
Abstrak
Pembelajaran belum memberikan gambaran nyata kepada peserta didik. Karena metode yang terbatas, guru perlu menggunakan metode lain. Keterampilan guru, aktivitas peserta didik dan hasil belajar belum maksimal. Berdasarkan masalahnya perlu diterapkan model pembelajaran Problem Based Learning (PBL) berbasis lingkungan bagi peserta didik. Penelitiannya menggunakan prosedur penelitian PTK yang terdiri dari empat langkah, yaitu merencanakan, melaksanakan tindakan, mengamati, dan merefleksi. Desain penelitiannya terdiri dari 4 tahap pada satu siklus. Instrumen pengumpulan data menggunakan teknik observasi, wawancara, studi dokumentasi dan lembar evaluasi. Teknik analisis data menggunakan analisis kualitatif dan kuantitatif. Hasil keterampilan guru memiliki persentase keberhasilan pada siklus I 76,56\% dan siklus II $89 \%$. Hasil aktivitas peserta didik memiliki persentase pada siklus I $62,5 \%$ dan siklus II 78\%. Hasil belajar peserta didik pada siklus I 70,3\% dan siklus II $85,18 \%$. Kesimpulannya model model pembelajaran Problem Based Learning (PBL) berbasis lingkungan yang diterapkan mampu meningkatkan kualitas pembelajaran.
\end{abstract}

Kata Kunci: problem based learning, berbasis lingkungan, penelitian tindakan kelas 


\section{PENDAHULUAN}

Perkembangan Kurikulum bertujuan untuk mempersiapkan manusia Indonesia agar memiliki kemampuan hidup sebagai pribadi dan warga negara yang beriman, produktif, kreatif, inovatif, dan afektif serta mampu berkontribusi pada kehidupan bermasyarakat, berbangsa, bernegara, dan peradaban dunia. Pencapaian tujuan tersebut maka penguatan materi dilakukan dengan cara pengurangan materi yang tidak relevan serta pendalaman dan perluasan materi yang relevan bagi peserta didik.

Guru dalam pelaksanaan pembelajaran mengalami kesulitan dalam memberikan gambaran secara nyata dan meyeluruh kepada peserta didik. Pembelajaran yang dilakukan guru terkenndala dari jumlah peserta didik yang terlalu banyak dan kondisi peserta didik yang tidak terfokus dengan materi yang diberikan oleh guru. Peserta didik dalam hal ini mengalami kesulitan memahami konsep dan aplikasi secara nyata di masyarakat. Selain itu bahan ajar yang digunakan hanya buku yang disediakan oleh sekolah, belum menggunakan tambahan bahan ajar serta model pembelajaran yang mampu memberikan gambaran nyata tentang proses pembentukan tanah kepada peserta didik.

Peserta didik kelas $\mathrm{V}$ yang ada di SDN Patemon 02 berdasar pada pengamatan yang telah dilakukan saat pembelajaran terlihat kurang aktif, serta dan kesulitan dalam pemahaman materi yang dibahas oleh guru. Hal ini memperlihatkan kemampuan dalam memahami materi dari segi pengetahuan, teknologi, lingkungan dan masyarakat sekitar belum terlihat. Oleh karena itu diperlukan tindakan yang serius dari guru agar tujuan dari pembelajaran dapat terwujud. Salah satunya menggunakan pendekatan dan model pembelajaran yang bervariasi.

Pembelajaran ini diperkuat dengan model pembelajaran Problem Based Learning (PBL), dimana proses pembelajaran yang paling sesuai adalah pembelajaran berbasis masalah itu sendiri. Sejumlah ciri atau karakteristik pada pembelajaran Problem Based Learning (PBL) menurut Tan (dalam Amir, 2009) antara lain: 1) Masalah digunakan sebagai awal pembelajaran; 2) Biasanya masalah yang digunakan merupakan masalah dunia nyata yang disajikan secara mengambang (ill-structured); 3 ) Masalah biasanya menuntut perspektif majemuk; 4) Masalah membuat pembelajar tertantang untuk mendapatkan pembelajaran di ranah pembelajaran yang baru; 5) Sangat mengutamakan belajar mandiri; 6) Memanfaatkan sumber pengetahuan yang bervariasi, tidak dari satu sumber saja, dan 7) Pembelajaran kolaboratif, komunikatif dan kooperatif. Karakteristik ini menuntut peserta didik untuk dapat menggunakan kemampuan berpikir tingkat tinggi, terutama kemampuan pemecahan masalah. Sintaks model problem based learning menurut Arends (2012) terdiri dari : 1) Orientasi; 2) Mengorganisasikan; 3) Membimbing; 4) Mengembangkan dan Menyajikan; 5) Manganalisis dan mengevaluasi. Penjelasan dia atas diperkuat dengan penelitian yang dilakukan oleh Anik Rochimah pada tahun 2015 dengan judul "Peningkatan Kualitas Pembelajaran Ipa Melalui Model Pembelajaran Problem Based Learning". Hasil penelitian menunjukkan bahwa penggunaan model pembelajaran problem based learning dapat meningkatkan kualitas pembelajaran IPA.

Pembelajaran ini juga berbasis lingkungan sebagai salah metode yang digunakan dalam pembelajaran tersebut dimana desain ini dapat dikembangkan suatu model persekolahan yang berorientasi pada lingkungan sekolah yang ada disekitar. Lingkungan (environment) sebagai dasar pengajaran adalah faktor kondisional yang mempengaruhi tingkah laku individu dan merupakan faktor belajar yang penting. (Hamalik, 2016). Penjelasan diatas diperkuat dengan penelitian yang dilakukan oleh Hervin Purnamawati pada tahun 2016 dengan judul "Pembelajaran Berbasis Lingkungan Sekitar Sekolah pada Siswa Kelas V SD N Deyangan 2". Hasil penelitian menunjukkan bahwa penggunaan pembelajaran berbasis lingkungan dapat meningkatkan kualitas pembelajaran yang dapat dilihat dari peningkatan aktivitas 
peserta didik, aktivitas guru, keterampilan proses dan afektif peserta didik yang berdampak pada peningkatan penguasaan konsep peningkatan prestasi belajar peserta didik.

Melihat kecenderungan yang ada dilapangan, peneliti tertarik untuk menerapkan Model Pembelajaran Problem Based Learning (PBL) Berbasis Lingkungan sebagai upaya meningkatkan Kualitas Pembelajaran Kelas V SD Negeri Patemon 02 Semarang untuk meningkatkan kemampuan berpikir ilmiah pada diri peserta didik. Penerapan model pembelajaran $\mathrm{PBL}$ ini juga berbasis lingkungan, dimana pembelajaran ini lebih fokus kepada pendekatan ilmiah (scientific approach) dalam pembelajaran sebagaimana dimaksud meliputi mengamati, menanya, menalar, mencoba, membentuk jejaring untuk semua mata pelajaran.

Rumusan masalah yang ditetapkan dalam penelitian ini adalah bagaimanakah cara meningkatkan kualitas Pembelajaran kelas V SD Negeri Patemon 02?. Tujuan dari penelitian ini untuk meningkatkan kualitas pembelajaran kelas V SD Negeri patemon 02. Manfaat dari penelitian ini memberikan perubahan pada pengembangan ilmu pengetahuan dan teknologi secara umum, serta dapat menjadi acuan bagi penelitian selanjutnya.

\section{METODE}

Penelitian ini dilaksanakan dengan langkah-langkah PTK, yaitu PTK dilaksanakan melalui proses pengkajian berdaur (cyclical) yang terdiri dari empat langkah, yaitu merencanakan (planning), melaksanakan tindakan (acting), mengamati (observing), dan merefleksi (reflecting). Desain penelitian yang digunakan seperti yang dijabarkan menurut Kemmis dan Mc Taggart (Aqib, 2011) Penelitian tindakan kelas ini terdiri dari 4 tahap pada satu siklus.

Subjek penelitian ini adalah guru dan peserta didik kelas V SD Negeri Patemon 02. Jumlah peserta didik yang akan diteliti sebanyak 27 orang yang terdiri dari 16 lakilaki dan 11 perempuan.

Jenis data diperoleh berupa keterampilan guru, aktivitas peserta didik, wawancara serta catatan lapangan. Tanpa mengetahui teknik pengumpulan data, maka peneliti tidak akan mendapatkan data yang memenuhi standar data yang ditetapkan (Sugiyono, 2011). Berikut teknik pengumpulan data terdiri dari teknik observasi, wawancara, studi dokumentasi dan lembar soal evaluasi peserta didik. Teknik analisis data menggunakan analisis kualitatif dan kuantitatif. Analisis kualitatif untuk Data yang dianalisis berupa keterampilan guru, aktifitas peserta didik, dan hasil belajar peserta didik dalam pembelajaran. Analisis kuantitatif untuk hasil pembelajaran yang akan dianalisis dengan menggunakan teknik analisis deskriptif dengan menentukan mean, median dan modus.

\section{HASIL PENELITIAN DAN PEMBAHASAN}

Hasil observasi keterampilan guru, aktivitas peserta didik dan hasil belajar setiap siklusnya pada pembelajaran menggunakan model pembelajaran Problem Based Learning (PBL) berbasis lingkungan di kelas V SD Negeri Patemon 02 Semarang.

1. Hasil Observasi Keterampilan Guru

Keterampilan guru pada kegiatan pembelajaran terdapat pengaruh menggunakan model pembelajaran Problem Based Learning (PBL) berbasis lingkungan. Hasil keterampilan guru diobservasi dengan menggunakan instrumen lembar observasi keterampilan guru. Data hasil analisis observasi keterampilan guru dapat dilihat pada tabel 1.1. 
Tabel 1. Rekapitulasi Hasil Observasi Keterampilan Guru

\begin{tabular}{|c|c|c|c|c|c|c|c|}
\hline \multirow[b]{2}{*}{ No } & \multirow[b]{2}{*}{ Indikator } & \multicolumn{3}{|c|}{ Siklus I } & \multicolumn{3}{|c|}{ Siklus II } \\
\hline & & $\begin{array}{c}\text { Pert. } \\
1\end{array}$ & $\begin{array}{l}\text { Pert. } \\
2\end{array}$ & $\begin{array}{l}\text { rata- } \\
\text { rata }\end{array}$ & $\begin{array}{c}\text { Pert. } \\
1\end{array}$ & $\begin{array}{l}\text { Pert. } \\
2\end{array}$ & $\begin{array}{l}\text { rata } \\
\text {-rata }\end{array}$ \\
\hline 1. & $\begin{array}{l}\text { Melaksanakan pra } \\
\text { pembelajaran }\end{array}$ & 3 & 3 & 3 & 3 & 4 & 3,5 \\
\hline 2. & Membuka pelajaran & 3 & 4 & 3,5 & 3 & 4 & 3,5 \\
\hline 3. & $\begin{array}{l}\text { Menggali pengetahuan } \\
\text { peserta didik }\end{array}$ & 3 & 3 & 3 & 4 & 4 & 4 \\
\hline 4. & $\begin{array}{l}\text { Membagikan LKPD } \\
\text { kepada setiap kelompok }\end{array}$ & 3 & 3 & 3 & 4 & 4 & 4 \\
\hline 5. & $\begin{array}{l}\text { Membimbing peserta } \\
\text { didik dalam diskusi } \\
\text { kelompok }\end{array}$ & 4 & 4 & 4 & 4 & 4 & 4 \\
\hline 6. & $\begin{array}{l}\text { Memberi kesempatan } \\
\text { peserta didik } \\
\text { mempersentasikan }\end{array}$ & 2 & 2 & 2 & 3 & 3 & 3 \\
\hline 7. & $\begin{array}{l}\text { Memberi penguatan } \\
\text { dan koreksi terhadap } \\
\text { hasil diskusi peserta } \\
\text { didik yang kurang } \\
\text { sesuai }\end{array}$ & 3 & 3 & 3 & 3 & 3 & 3 \\
\hline 8. & Menutup pelajaran & 3 & 3 & 3 & 3 & 4 & 3,5 \\
\hline & $\begin{array}{c}\text { Jumlah skor } \\
\text { Kriteria }\end{array}$ & Baik & Baik & 24,5 & $\begin{array}{c}27 \\
\text { San } \\
\text { gat } \\
\text { Baik }\end{array}$ & $\begin{array}{c}30 \\
\text { San } \\
\text { gat } \\
\text { Baik }\end{array}$ & $\begin{array}{c}28,5 \\
\text { San } \\
\text { gat } \\
\text { Baik }\end{array}$ \\
\hline \multicolumn{2}{|c|}{ Persentase keberhasilan } & $75 \%$ & $\begin{array}{l}78,1 \\
2 \%\end{array}$ & $\begin{array}{c}76,5 \\
6 \%\end{array}$ & $\begin{array}{c}84,3 \\
\%\end{array}$ & $\begin{array}{l}93,7 \\
5 \%\end{array}$ & $89 \%$ \\
\hline
\end{tabular}

Pada salah satu nndikator keterampilan membimbing diskusi kelompok memperoleh skor 4. Hal yang telah dilakukan guru dalam pembelajaran siklus I maupun II adalah memperjelas permasalahan yang akan didiskusikan oleh siswa di dalam kelompok dan membimbing kelompok yang mengalami kesulitan. Guru juga menuntun peserta didik untuk menemukan jawaban. Selain itu menurut Rusman (2011) peranan guru yang berkaitan dengan kompetensi guru dalam melaksanakan proses pembelajaran salah satunya adalah melaksanakan diskusi dalam kelas.

Rekapitulasi observasi keterampilan guru ketika pembelajaran melalui model pembelajaran Problem Based Learning (PBL) berbasis lingkungan pada siklus I diperoleh skor 24,5 dengan kriteria baik dan siklus II diperoleh skor 28,5 dengan kriteria sangat baik, sedangkan persentase keberhasilan keterampilan guru pada siklus I mencapai $76,56 \%$ dan siklus II mencapai $89 \%$.

2. Hasil Observasi Aktivitas Peserta Didik

Aktivitas peserta didik pada kegiatan pembelajaran terdapat pengaruh menggunakan model pembelajaran Problem Based Learning (PBL) berbasis lingkungan. Hasil aktivitas peserta didik diobservasi dengan menggunakan instrumen lembar observasi aktivitas peserta didik. Data hasil analisis observasi aktivitas peserta didik dapat dilihat pada tabel 1.2 . 
Tabel 2. Rekapitulasi Hasil Observasi Aktivitas Peserta Didik

\begin{tabular}{|c|c|c|c|c|c|c|c|}
\hline \multirow[b]{2}{*}{ No } & \multirow[b]{2}{*}{ Indikator } & \multicolumn{3}{|c|}{ Siklus I } & \multicolumn{3}{|c|}{ Siklus II } \\
\hline & & $\begin{array}{c}\text { Pert. } \\
1\end{array}$ & $\begin{array}{l}\text { Pert. } \\
2\end{array}$ & $\begin{array}{l}\text { rata- } \\
\text { rata }\end{array}$ & $\begin{array}{l}\text { Pert. } \\
1\end{array}$ & $\begin{array}{l}\text { Pert. } \\
2\end{array}$ & $\begin{array}{c}\text { rata - } \\
\text { rata }\end{array}$ \\
\hline 1. & $\begin{array}{l}\text { Mempersiapakan diri } \\
\text { dalam } \\
\text { menerima pelajaran }\end{array}$ & 2,58 & 2,85 & 2,71 & 3,16 & 3,71 & 3,43 \\
\hline 2. & Menjawab pertanyaan & 2,64 & 2,91 & 2,77 & 3,39 & 3,46 & 3,42 \\
\hline & $\begin{array}{l}\text { memperhatikan } \\
\text { penjelasan dari guru }\end{array}$ & 2,52 & 2,75 & 2,63 & 3,03 & 3,21 & 3,12 \\
\hline 4. & $\begin{array}{l}\text { Bekerja dalam } \\
\text { kelompok }\end{array}$ & 2,64 & 2,82 & 2,73 & 3,10 & 3,37 & 3,23 \\
\hline 5. & $\begin{array}{l}\text { Mempersentasikan } \\
\text { hasil diskusi } \\
\text { berdasarkan } \\
\text { pertanyaan }\end{array}$ & 2,67 & 2,82 & 2,74 & 3,23 & 3,25 & 3,24 \\
\hline 6. & $\begin{array}{l}\text { Menanyakan hal-hal } \\
\text { yang belum dipahami }\end{array}$ & 1,47 & 2,05 & 1,76 & 2,70 & 3,01 & 2,85 \\
\hline 7. & $\begin{array}{l}\text { Bersama guru, peserta } \\
\text { didik melakukan } \\
\text { refleksi terhadap } \\
\text { kegiatan yang telah } \\
\text { dilaksanakan }\end{array}$ & 2,2 & 2,47 & 2,33 & 2,77 & 3,06 & 2,91 \\
\hline 8. & $\begin{array}{l}\text { Membuat kesimpulan } \\
\text { mengenai proses } \\
\text { pembelajaran }\end{array}$ & 2,32 & 2,35 & 2.33 & 2,64 & 2,93 & 2,78 \\
\hline & Jumlah skor & $\begin{array}{c}19,0 \\
4\end{array}$ & 21,02 & 20 & 24,02 & 26 & 24,98 \\
\hline & Kriteria & $\begin{array}{l}\text { Cuk } \\
\text { up }\end{array}$ & Baik & Baik & Baik & Baik & Baik \\
\hline & sentase keberhasilan & $\begin{array}{c}59,5 \\
\%\end{array}$ & $\begin{array}{c}65,68 \\
\%\end{array}$ & $\begin{array}{c}62,5 \\
\%\end{array}$ & $\begin{array}{c}75,06 \\
\%\end{array}$ & $\begin{array}{l}81,2 \\
5 \%\end{array}$ & $78 \%$ \\
\hline
\end{tabular}

Salah satu indikator pada aktivitas peserta didik yaitu kesiapan belajar peserta didik dalam menerima pelajaran sudah baik pada pelaksanaan tindakan siklus I maupun siklus II. Hal ini terlihat pada saat memasuki kelas sebagian besar peserta didik datang tepat waktu dan sudah berada ditempat duduk masing-masing serta memepersiapkan perlengkapan. Semua peserta didik membawa alat tulis dan juga buku pegangan yang digunakan untuk belajar. Peserta didik yang memperhatikan penjelasan guru hampir sebagian besar. Sesuai juga dengan pendapat Hamdani (2011) prinsip-prinsip belajar dalam pembelajaran adalah kesiapan belajar; perhatian; motivasi; keaktifan peserta didik; mengalami sendiri; pengulangan; materi pelajaran yang menantang; balikan dan penguatan; perbedaan individual.

Rekapitulasi observasi aktivitas peserta didik saat pembelajaran melalui model pembelajaran Problem Based Learning (PBL) berbasis lingkungan pada siklus I diperoleh skor 20 dengan kriteria baik dan siklus II diperoleh skor 24,98 dengan kriteria baik. sedangkan persentase keaktivitan peserta didik pada siklus I mencapai $62,5 \%$ dan siklus II mencapai $78 \%$.

3. Observasi Hasil Belajar Peserta Didik

Rekapitulasi hasil belajar peserta didik dalam pembelajaran pembelajaran melalui model pembelajaran Problem Based Learning (PBL) berbasis lingkungan pada pra siklus, siklus I dan siklus II diperoleh data sebagai berikut: 
Tabel 3. Rekapitulasi Observasi Hasil Belajar Peserta Didik

\begin{tabular}{clccc}
\hline No. & \multicolumn{1}{c}{ Aspek } & Pra Siklus & Siklus I & Siklus II \\
\hline 1. & Nilai Rata-rata & 65,92 & 75,55 & 81,48 \\
2. & Nilai tertinggi & 100 & 100 & 100 \\
3. & Nilai terendah & 20 & 40 & 40 \\
4. & $\begin{array}{l}\text { Peserta didik yang } \\
\text { tuntas }\end{array}$ & 11 & 19 & 23 \\
5. & $\begin{array}{l}\text { Peserta didik yang } \\
\text { tidak tuntas }\end{array}$ & 16 & 8 & 4 \\
6. & $\begin{array}{l}\text { Persentase } \\
\text { ketuntasan }\end{array}$ & $40,7 \%$ & $70,3 \%$ & $85,18 \%$ \\
7. & $\begin{array}{l}\text { Persentase } \\
\text { ketidaktuntasan }\end{array}$ & $59,3 \%$ & $29,7 \%$ & $14,82 \%$ \\
\hline
\end{tabular}

Rekapitulasi observasi hasil belajar peserta didik pada pembelajaran melalui pembelajaran melalui model pembelajaran Problem Based Learning (PBL) berbasis lingkungan dari siklus I diperoleh rata-rata 75,55 dengan persentase ketuntasan mencapai $70,3 \%$ dan siklus II diperoleh rata-rata 81,48 dengan persentase ketuntasan mencapai $85,18 \%$.

Berdasar hasil rekapitulasi hasil belajar peserta didikpada siklus I dan siklus II sesuai dengan pemikiran Gagne (dalam Suprijono, 2012), hasil belajar berupa Informasi verbal yaitu kapabilitas mengungkapkan pengetahuan dalam bentuk bahasa, baik lisan maupun tertulis, keterampilan intelektual yaitu kemampuan mempresentasikan konsep dan lambang dan strategi kognitif yaitu kecakapan menyalurkan dan mengarahkan aktivitas kognitifnya sendiri.

\section{SIMPULAN}

Berdasarkan hasil penelitian dan pembahasan yang dilakukan pada penerapan model pembelajaran Problem Based Learning (PBL) berbasis lingkungan saat pembelajaran dapat ditarik kesimpulan bahwa model tersebut dapat meningkatkan keterampilan guru, aktivitas peserta didik dan hasil belajar dari peserta didik. Keterampilan guru disini mengalami peningkatan dari siklus I diperoleh skor 24,5 dengan kriteria baik dan siklus II diperoleh skor 28,5 dengan kriteria sangat baik, sedangkan persentase keberhasilan keterampilan guru pada siklus I mencapai 76,56\% dan siklus II mencapai $89 \%$. Aktivitas peserta didik juga mengalami peningkatan dari siklus I diperoleh skor 20 dengan kriteria baik dan siklus II diperoleh skor 24,98 dengan kriteria baik. sedangkan persentase keaktivitan peserta didik pada siklus I mencapai $62,5 \%$ dan siklus II mencapai $78 \%$. Hasil Belajar juga mengalami peningkatan dari siklus I diperoleh rata-rata 75,55 dengan persentase ketuntasan mencapai 70,3\% dan siklus II diperoleh rata-rata 81,48 dengan persentase ketuntasan mencapai 85,18 \%. 
DAFTAR PUSTAKA

Amir, T.M, 2013. Inovasi Pendidikan melalui Problem Based Learning: Bagaimana Pendidik Memberdayakan Pembelajar di Era Pengetahuan. Jakarta: Kencana Prenada Media Group.

Aqib, Zainal dkk. 2011. Penelitian Tindakan Kelas untuk Guru SD, SLB, dan TK. Bandung: Yrama Widya.

Arends, R.I. 2012. Learning to Teach. New York: McGraw-Hill Companies, Inc.

Hamalik, Oemar. 2016. Proses Belajar Mengajar. Jakarta: Bumi Aksara.

Hamdani. 2011. Strategi Belajar Mengajar. Bandung: Pustaka Setia.

Purnamawati, Herfin. 2016. Pembelajaran Berbasis Lingkungan Sekitar Sekolah Pada Siswa Kelas V SD N Deyangan 2. Jurnal Pendidikan Guru Sekolah Dasar. Edisi 30. Tahun ke-5

Rochimah, Anik. 2015. Peningkatan Kualitas Pembelajaran IPA Melalui Model Pembelajaran Problem Based Learning. Joyful Learning Journal. Vol 4 No 3.

Rusman. 2011. Model-Model Pembelajaran Mengembangkan Profesionalisme Guru. Jakarta: Rajagrafindo Persada.

Sugiyono. 2011. Metode Peneltian Kuantitatif, Kualitatif dan $R \& D$. Bandung: Alfabeta

Suprijono, Agus. 2012. Cooperative Learning.Yogyakarta: Pustaka Pelajar. 